\title{
Some new insights into the geochronology of the Western Karelia Subprovince, Finnish Lapland
}

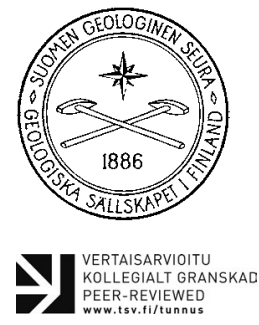

\author{
Johanna Tepsell ${ }^{*}$, O. Tapani Ramö ${ }^{\mathrm{I}}$, Aku Heinonen ${ }^{\mathrm{I}}$, Yann \\ Lahaye $^{2}$, Pieti Haapala ${ }^{\mathrm{I}, 3}$, Tapio Halkoaho ${ }^{4}$, Jussi S. Heinonen ${ }^{\mathrm{I}}$, \\ Henri Höytiä ${ }^{I, 5}$, Jukka Konnunaho ${ }^{6}$ and Ville Järvinen ${ }^{1}$ \\ ${ }^{1}$ Department of Geosciences and Geography, P.O. Box 64, FIN-00014 University of \\ Helsinki, Finland \\ ${ }^{2}$ Geological Survey of Finland, P.O. Box 96, FIN-02151 Espoo, Finland \\ ${ }^{3}$ A-Insinöörit Civil Oy, Bertel Jungin aukio 9, FIN-02600, Espoo, Finland \\ ${ }^{4}$ Geological Survey of Finland, P.O. Box 1237, FIN-70211 Kuopio, Finland \\ ${ }^{5}$ Anglo American Exploration, AA Sakatti Mining Oy, Tuohiaavantie 2, FIN-99600 \\ Sodankylä, Finland \\ ${ }^{6}$ Geological Survey of Finland, P.O. Box 77, FIN-96101 Rovaniemi, Finland
}

\begin{abstract}
Archean terranes are generally poorly exposed and structurally complicated, making models of geological evolution difficult to establish. Because of pervasive metamorphism, strong deformation, and poorly exposed bedrock, the stratigraphy, geochronology, and geological evolution of the northeastern part of the Archean Western Karelia Subprovince, Finnish Lapland, is still deficient. Three new U-Pb age determinations were made using the LA-ICP-MS method on zircon in search of more profound understanding of the geochronology of the area. Data from the Pultoselkä granite yield an age of $2795 \pm 5 \mathrm{Ma}$, providing a minimum age of $2.8 \mathrm{Ga}$ for the Tulppio suite. The age is coeval with widespread 2.74-2.70 Ga granitoids of the Karelia Province, likely representing the same magmatic event. The data from the Kontioselkä pegmatite define a maximum age for the pegmatite and a minimum age for mafic volcanic rocks in Kontioselkä at $1781 \pm 27 \mathrm{Ma}$. The age coincides with major deformation and metamorphism in the Karelia Province around $1.76 \mathrm{Ga}$. Zircon from the Jänesselkä mafic-ultramafic complex yields a minimum age of $2425 \pm 17 \mathrm{Ma}$, complying rather well with the 2.5-2.4 Ga mafic layered intrusions of the northern Fennoscandian Shield. Our new data show that the Archean of the northeastern part of the Western Karelia Subprovince was affected by Proterozoic thermal events more extensively than thus far perceived.
\end{abstract}

Keywords: Geochronology, U-Pb, Zircon, ICP-MS, Eastern Lapland, Archean, Finland, $2.44 \mathrm{Ga}$ mafic layered intrusions

* Corresponding author (email: johanna.tepsell@helsinki.fi)

Editorial handling: Niina Kuosmanen (e-mail: kuosmanen.niina@gmail.com) 


\section{Introduction}

Archean and Paleoproterozoic terranes are in many cases structurally complicated and generally poorly exposed, rendering stratigraphic interpretations and models of geological evolution hard to establish. The northeastern parts of the Western Karelia Subprovince (WKS, the study area), covering a large part of the municipalities of Salla and Savukoski in northeastern Finland (Fig. 1), is no exception. The first bedrock studies in the area were carried out by Mikkola (1936) as a part of the mapping endeavour of Finnish Lapland (Mikkola, 1941). Mikkola’s work was followed by a more comprehensive bedrock study by Juopperi (1994), which today serves as the base of the geological interpretations of the northeastern part of the WKS. The geology of the area is, however, still only vaguely known and somewhat debated because of medium- to high-grade metamorphic overprint (Piirainen et al., 1985; Virransalo 1985) and predominant thrust tectonics (Papunen et al., 1997). The geological evolution and age relations of several local mafic-ultramafic bodies are especially poorly known (Fig. 1). As currently perceived, most of these ultramafic bodies are komatiitic in origin (Kauniskangas, 1987; Juopperi, 1994; Papunen et al., 1997) and some of the mafic-ultramafic bodies may be linked to the $2.44 \mathrm{Ga}$ layered intrusion magmatism (Juopperi \& Vaasjoki, 2001; Huhma et al., 2018).

The geochronology of the north WKS has been described by Juopperi \& Vaasjoki (2001) and Huhma et al. (2018). Hitherto, $15 \mathrm{U}-\mathrm{Pb}$ age determinations on felsic, mostly granitic and tonalitic bodies have been published. In addition, three mafic-ultramafic intrusions have been dated using the $\mathrm{Sm}-\mathrm{Nd}$ method. Relative ages of ultramafic sequences have mostly been interpreted based on rather obscure field relations to adjacent granitoids. The amount and extent of Paleoproterozoic intrusions within the Archean complexes of the northeastern part of the WKS are also poorly known.
In order to establish a better understanding of the geochronology of the area, zircon grains were dated from three new samples from the WKS using the U-Pb LA-ICP-MS technique. The samples were collected in the framework of a Geological Survey of Finland and University of Helsinki joint project "Modeling of $\mathrm{Ni}$-(Cu-PGE)-bearing mineral systems; the origin, exploration potential, and metallogeny of ultramafic volcanic suites of eastern Lapland". The obtained data improve the knowledge on the crystallization ages of the Pultoselkä granitoid, Kontioselkä pegmatite, and Jänesselkä mafic-ultramafic body (Fig. 1). They provide further constraints to the age relations between Paleoproterozoic and Archean rocks in the Finnish northeastern corner of the WKS and thus also help in deciphering the temporal evolution of the bedrock of eastern Lapland.

\section{Geological setting}

The WKS represents the southwestern part of the Archean domain of the Fennoscandian Shield (Fig. 1). Together with the Central Karelia Subprovince it constitutes the Finnish part of the Karelia Province (Luukas et al., 2017). The

Figure 1. Geological map of the northeastern part of the Western Karelia Subprovince (modified after Bedrock of Finland, DigiKP - Seamless bedrock map of Finland by GTK) showing the localities of the studied U-Pb samples (see Haapala et al., 2019). Also shown are the previously published Rb-Sr (Vartiainen \& Woolley, 1974), U-Pb (Juopperi \& Vaasjoki, 2001), and Sm-Nd (Huhma et al., 2018) age data. Inset shows schematic map of tectonic provinces in the Fennoscandian Shield with the study area in the northeastern part of the Western Karelia Subprovince highlighted in grey (modified from Bibikova et al., 2001; Koistinen et al., 2001; Bingen et al., 2008; Nironen, 2017). Fennoscandian Shield shown by dashed black line, province boundaries by red solid lines. Dashed blue line marks the boundary between Western Karelia Subprovince and Central Karelia Subprovince. Coordinate system is EUREF-FIN. Abbreviations: $\mathrm{KhC}=$ Kemihaara granitoid complex, TuS = Tulppio suite, TS = Tuntsa suite, $\mathrm{NaC}=$ Naruska granitoid complex, WKS = Western Karelia Subprovince, and CKS = Central Karelia Suprovince. 


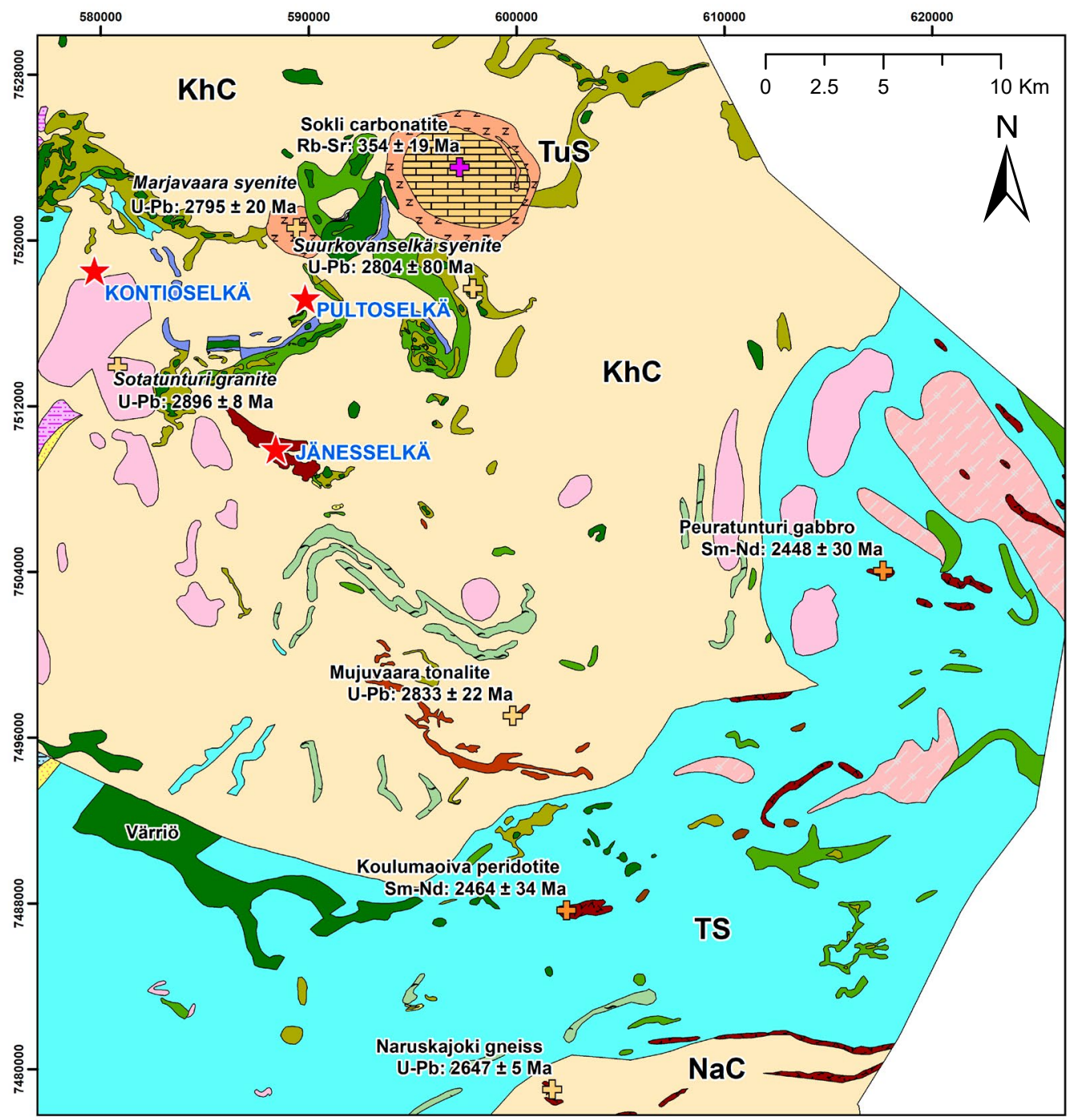

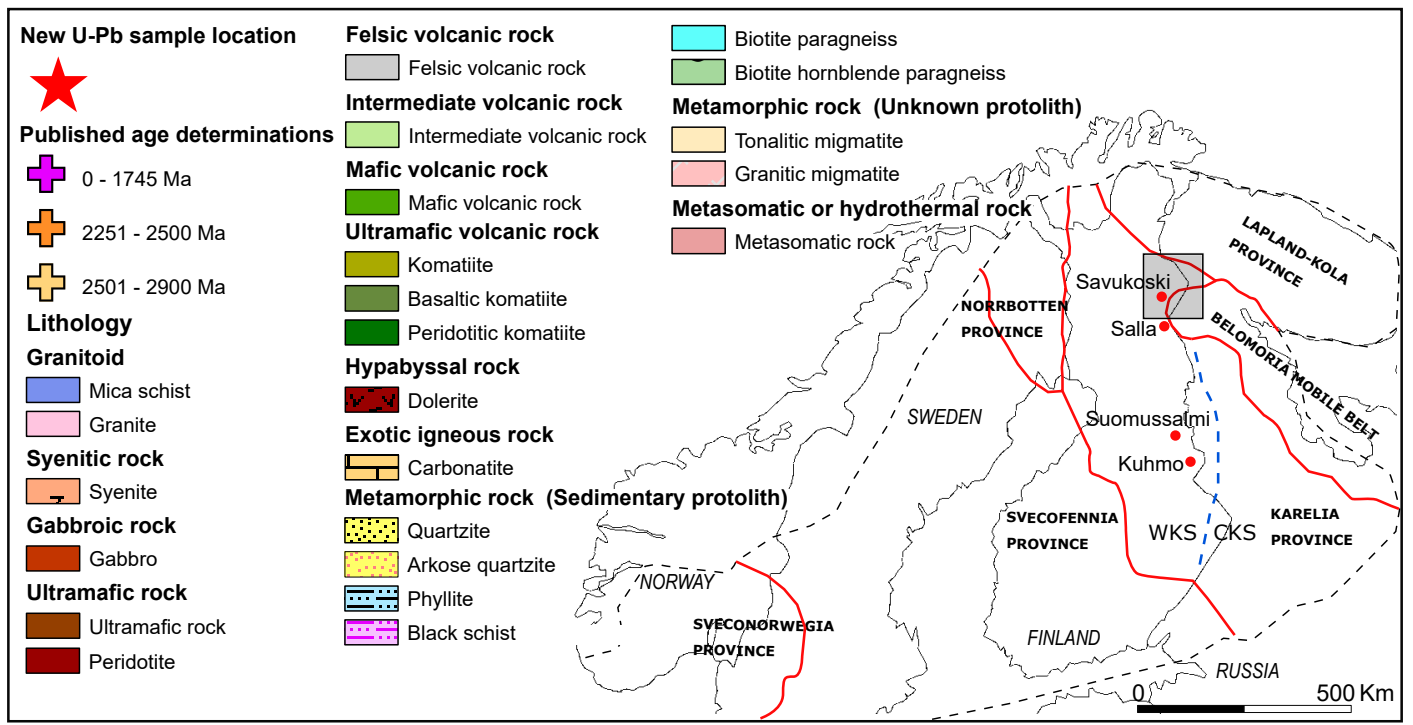


area belongs to the larger tectonic Karelia Province, continuing to Russia, characterized by highly metamorphosed Archean basement and Paleoproterozoic supracrustal rocks (Slabunov et al., 2006; Luukas et al., 2017). Some of the gneisses in the northeastern part of the WKS are, however, considered as part of the Archean Belomorian Mobile Belt (Fig. 1; Gaál \& Gorbatsev, 1987; Juopperi, 1994; Hölttä et al., 2008; Luukas et al., 2017).

The bedrock of the northern WKS is characterized by two large granitoid complexes surrounding two E-W trending supracrustal suites that include abundant mafic-ultramafic rocks. These four major units, divided by lithotectonic means are, from north to south (Fig. 1), the Kemihaara granitoid complex (KhC), Tulppio suite (TuS), Tuntsa suite (TS), and Naruska granitoid complex $(\mathrm{NaC})$ (Luukas et al., 2017), all of which are considered Archean (Juopperi \& Vaasjoki, 2001). Of the two supracrustal suites, the $\mathrm{TuS}$ is mainly composed of metavolcanic rocks, while the TS is mainly composed of metasedimentary rocks (Mikkola, 1941; Juopperi, 1994). The four major lithotectonic units are cut by Paleoproterozoic intrusions with compositions ranging from mafic-ultramafic to felsic. Three of the mafic-ultramafic intrusions were dated by Huhma et al. (2018) using the Sm-Nd method (see Fig. 1): the Värriö ultramafic intrusion (ca. $2.4 \mathrm{Ga}$ ), Koulumaoiva ultramafic intrusion $(2464 \pm 34 \mathrm{Ma})$, and Peuratunturi gabbroic intrusion $(2448 \pm 30 \mathrm{Ma})$. The ages of other ultramafic sequences are ambiguous and based on rather unclear relations to the adjacent ca. 2.9-2.5 Ga granitoids (Juopperi \& Vaasjoki, 2001).

In our work, three new samples from key locations were collected in search of a more profound understanding on the geochronology of the area (Fig. 1). These samples were collected from 1) a granitoid at Pultoselkä within the $\mathrm{KhC}, 2)$ a granitic pegmatite croscutting the $\mathrm{TuS}$ at Kontioselkä, and 3) a gabbro representing a poorly defined mafic-ultramafic body in $\mathrm{TuS}$ at Jänesselkä.

\section{Analytical methods}

Sample preparation for the U-Pb analyses was carried out at the Geological Survey of Finland. Samples were washed, crushed, and heavy minerals were separated using methylene iodide and Clerici ${ }^{\circledR}$ solution. An isodynamic separator (Frantz; 0.5 A and $1.4 \mathrm{~A}$ ) was used to separate non-magnetic fractions. The zircon fractions were hand-picked from the non-magnetic heavy fractions under a binocular microscope, mounted in epoxy resin, and polished to surface. Before analysis, BSE (Back-Scattered Electron) images were acquired of the mounts using a low vacuum scanning electron microscope JEOL JSM 5900 LV SEM.

LA-ICP-MS analyses were performed at the Geological Survey of Finland in Espoo utilizing a Nu Plasma AttoM SC-ICP-MS (Single Collector Inductively Coupled Plasma Mass Spectrometer) instrument attached to Photon Machine Excite laser ablation system (ArF, 4ns, $193 \mathrm{~nm}$ ). Samples were ablated in $\mathrm{He}$ gas (gas flow $0.15 \mathrm{l} / \mathrm{min}$ and $0.4 \mathrm{l} / \mathrm{min}$ ) in a static ablation mode with a beam diameter of $25 \mu \mathrm{m}$, pulse frequency of $5 \mathrm{~Hz}$, and beam energy density of $2.5 \mathrm{~J} / \mathrm{cm}^{2}$. The He aerosol was mixed with Ar gas (gas flow $=0.931 / \mathrm{min}$ ) prior entry into the plasma. A single measurement included a $5 \mathrm{~s}$ pre-ablation, $20 \mathrm{~s}$ background measurement on-mass, and $40 \mathrm{~s}$ ablation in static ablation mode. Two calibration standards together with an in-house external standard were measured as duplicates at the beginning and at the end of every session and also between every 10-25 analyses. Mass 204 was used to monitor common lead $\left({ }^{204} \mathrm{~Pb}\right)$ content. ${ }^{235} \mathrm{U}$ was calculated from the signal on ${ }^{238} \mathrm{U}$ using the natural ${ }^{238} \mathrm{U} /{ }^{235} \mathrm{U}$ ratio of $137.88 .{ }^{204} \mathrm{Hg}$ induced interference was eliminated by on-mass measurement prior to every analysis.

Age-related common lead correction outlined by Stacey \& Kramers (1975) was used for analyses with common lead content exceeding the detection limit. Raw data were corrected for background, laser-induced elemental fractionation, mass discrimination, and drift in ion counter gains. An in-house standard zircon A382 from a pyroxene 
bearing granite (1877 $\pm 2 \mathrm{Ma}$; Huhma et al., 2012) was used for calibration. A second in-house standard zircon A1772 from an Archean gabbro (2711 $\pm 3 \mathrm{Ma}$; Huhma et al., 2012) and a gemquality standard zircon GJ-1 (609 $\pm 1 \mathrm{Ma}$; Jackson et al., 2004; Belousova et al., 2006) were used for quality control. Measured signal ratios were converted into isotopic ratios using the Glitter program (Van Achterbergh et al., 2001). Further data reduction including common lead correction and error propagation was performed. U-Pb isotope data were plotted and age calculations were performed using the Isoplot/Ex 3.0 software (Ludwig, 2003). All ages were calculated with $2 \sigma$ errors without decay constant errors.

\section{Results}

\subsection{Samples and internal texture of zircon}

\subsubsection{Granitoid - Pultoselkä}

The Pultoselkä granitoid, represented by sample HMHO-2017-10.1 (Fig. 1 and Table 1), is a typical example of the many relatively widespread granitoids in the northern WKS. The main minerals are potassium feldspar, quartz, biotite, and plagioclase. The rock is medium-grained, reddish, foliated, and located adjacent to the mafic-ultramafic volcanic rocks of the Tulppio suite. The contact between the granite and the TS, however, was not apparent. The biotite granite (HMHO-2017-10.1) yielded abundant zircon for $\mathrm{U}-\mathrm{Pb}$ dating. The extracted zircon grains (Fig. 2A) are mostly euhedral, well-preserved, and pale brown. Oscillatory zoning, typical of magmatic zircon, is clearly visible in most of the grains. Local recrystallization is seen in some of the grains as irregular darker homogenous patches crosscutting the magmatic zoning. The grain size of the separated zircon fraction is relatively homogenous (length $130-230 \mu \mathrm{m})$ with a length to breadth ratio (L/B) of ca. 3. The majority of the grains shows wide, intensively and radially cracked rims possibly indicating later growth of low-U zircon. A distinct dark homogeneous zone is observed between the core and the rim (Fig. 2A).

\subsubsection{Pegmatite - Kontioselkä}

Sample HMHO-2017-16.1 is from a NW-trending coarse-grained granitic pegmatite dyke crosscutting the mafic volcanic rocks of the Tulppio suite at Kontioselkä (Fig.1 and Table 1). The pegmatite exhibits magmatic textures and seems undeformed. The Kontioselkä pegmatite sample (HMHO-2017$16.1)$ yielded a very small amount of heavy minerals $\left(>4.2 \mathrm{~g} / \mathrm{cm}^{3}\right)$ and only a few grains of extensively altered subhedral prismatic zircon were obtained. The zircon grains (Fig. 2B) are highly metamict, locally recrystallized, full of inclusions, turbid, brownish grey, and varying in size (length 200-600 $\mu \mathrm{m})$. Complex alteration and recrystallization are seen as lighter botryoidal and bulbous domains within the crystals creating a highly irregular patchy, mosaic texture. Nonetheless, rather homogeneous rims are present in few of the grains (Fig. 2B). One anomalous grain showed magmatic zoning. The L/B ratio varies from 3 in large grains to 1 in small grains.

\subsubsection{Gabbro - Jänesselkä}

Sample JHTE-2017-35.2 is from the Jänesselkä mafic-ultramafic body (Fig.1 and Table 1) located a few kilometres south of the Tulppio suite (Haapala, 2019). The bedrock in the Jänesselkä area is well exposed and a gradual change from an anorthositic body (few meters southwest from the sample point) to ultramafic rocks is observed. Because of the continuous rock association and similar deformation history, the rocks of the Jänesselkä area are considered to belong to the same intrusive phase (see Peltoniemi, 1984; Piirainen et al., 1985; Papunen et al., 1997; Haapala, 2019). The sample is from a coarse-grained amphibole-bearing gabbroic differentiate exposed in the central part of maficultramafic body. The heavy mineral fraction recovered from the gabbro (sample JHTE-2017-35.2) 
Table 1. U-Pb geochronological samples analyzed in this study.

\begin{tabular}{lllll}
\hline Sample & Lat. EUREF-FIN & Long. EUREF-FIN & Locality & Rock type \\
\hline HMHO-2017-10.1 & 7517190 & 589833 & Pultoselkä & Biotite granite \\
\hline HMHO-2017-16.1 & 7518540 & 579704 & Kontioselkä & Granite pegmatite \\
\hline JHTE-2017-35.2 & 7509928 & 588432 & Jänesselkä & Gabbro \\
\hline
\end{tabular}

contains abundant rutile with few zircon. The extracted zircon grains (Fig. 2C) are subhedral prisms or anhedral fragments. Most of the grains are altered and metamict, spongy, locally recrystallized, full of inclusions, and pale brown. Magmatic zoning is visible only in a few grains, the rest show distinct marks of recrystallization. Modification of magmatic zircon is seen as disrupted concentric oscillatory zoning followed by irregular homogenous replacement or recrystallization texture (Fig. 2C). The recrystallized zircon shows darker, faint bulbous, wavy, and feathery propagation patterns. Homogeneous rims are common (Fig. 2C). The $\mathrm{L} / \mathrm{B}$ ratio for the subhedral zircon fraction varies from 1.5 to 2.5 .

\subsection{LA-ICP-MS U-Pb geochronology}

Analyses of 35 zircon grains from the Pultoselkä biotite granite, on 48 spots, have low common lead content and are mostly concordant with two distinct age populations (Fig. 2A and Electronic Appendix A). Five analyses were rejected owing to high common lead $\left({ }^{206} \mathrm{Pd} /{ }^{204} \mathrm{~Pb}<4000\right)$. The $\mathrm{Th} / \mathrm{U}$ ratio of the analyzed zircon varies from 0.14 to 0.67 . Analyses of the best-preserved domains yielded a concordia age of $2795 \pm 5 \mathrm{Ma}$, which may be considered as the crystallization age of the biotite granite. Concordant analyses of darker recrystallized homogenous domains, lacking the magmatic zoning, yielded a younger concordia age of $2716 \pm 12 \mathrm{Ma}$. Pb-Pb ages of the two distinct age groups are consistent with the corresponding $\mathrm{U}-\mathrm{Pb}$ ages with an average of $2794 \pm 13 \mathrm{Ma}(\mathrm{n}=31)$ for the older concordant population and an average of $2713 \pm 15 \mathrm{Ma}(\mathrm{n}=7)$ for the younger concordant population. One clearly older grain is distinct showing crisp, regular, and concentric zoning, typical of magmatic zircon, with coarser growth bands compared to the other zircon (Fig. 2A). The zircon represents either an inherited Archean zircon or contamination in the sample preparation process. Analyses of grain rims and pervasively recrystallized zircon domains are younger and discordant.

Analyses of 19 zircon grains from the Kontioselkä granite pegmatite (32 spots) have high common lead and yield scattered results (Fig. 2B and Electronic Appendix A). Rejecting data with high common lead content $\left({ }^{206} \mathrm{~Pb} /{ }^{204} \mathrm{~Pb}<4000\right)$, the remaining analyses define a discordia with intercepts at $1781 \pm 27 \mathrm{Ma}$ and $417 \pm 27 \mathrm{Ma}$. The three oldest, somewhat discordant zircon analyses yielded a slightly older $\mathrm{Pb}-\mathrm{Pb}$ age of $1811 \pm 20 \mathrm{Ma}$. The $T h / U$ ratio of the analyzed zircon is low, varying from 0.01 to 0.54 with a mean of 0.09 . One concordant analysis (Fig. 2B), representing a distinctly small, euhedral, and magmatically zoned zircon was rejected, most likely being obtained by contamination during heavy mineral separation. The upper intercept age at $1781 \pm 27 \mathrm{Ma}$ is the best estimate of the crystallization age of the pegmatite and, thus, also the minimum age of the Kontioselkä mafic volcanic rock.

Analyses of 28 zircon grains from the Jänesselkä gabbro, on 46 spots, yielded widely scattered, partly discordant LA-ICP-MS data (Fig. 2C and Electronic Appendix A). Analyses showing the lowest common lead content $\left({ }^{206} \mathrm{~Pb} /{ }^{204} \mathrm{~Pb}>4000\right)$ were used for calculations. The oldest ages spread along the concordia between ca. 2.4-2.1 Ga and appear to be best-preserved from pale homogeneous domains. An additional set of seven analyses plot along the concordia around $1.85 \mathrm{Ga}$, possibly indicating a younger major deformation event that affected the $\mathrm{U}-\mathrm{Pb}$ system of the igneous grains. The rest of the analyses are mostly discordant and define 

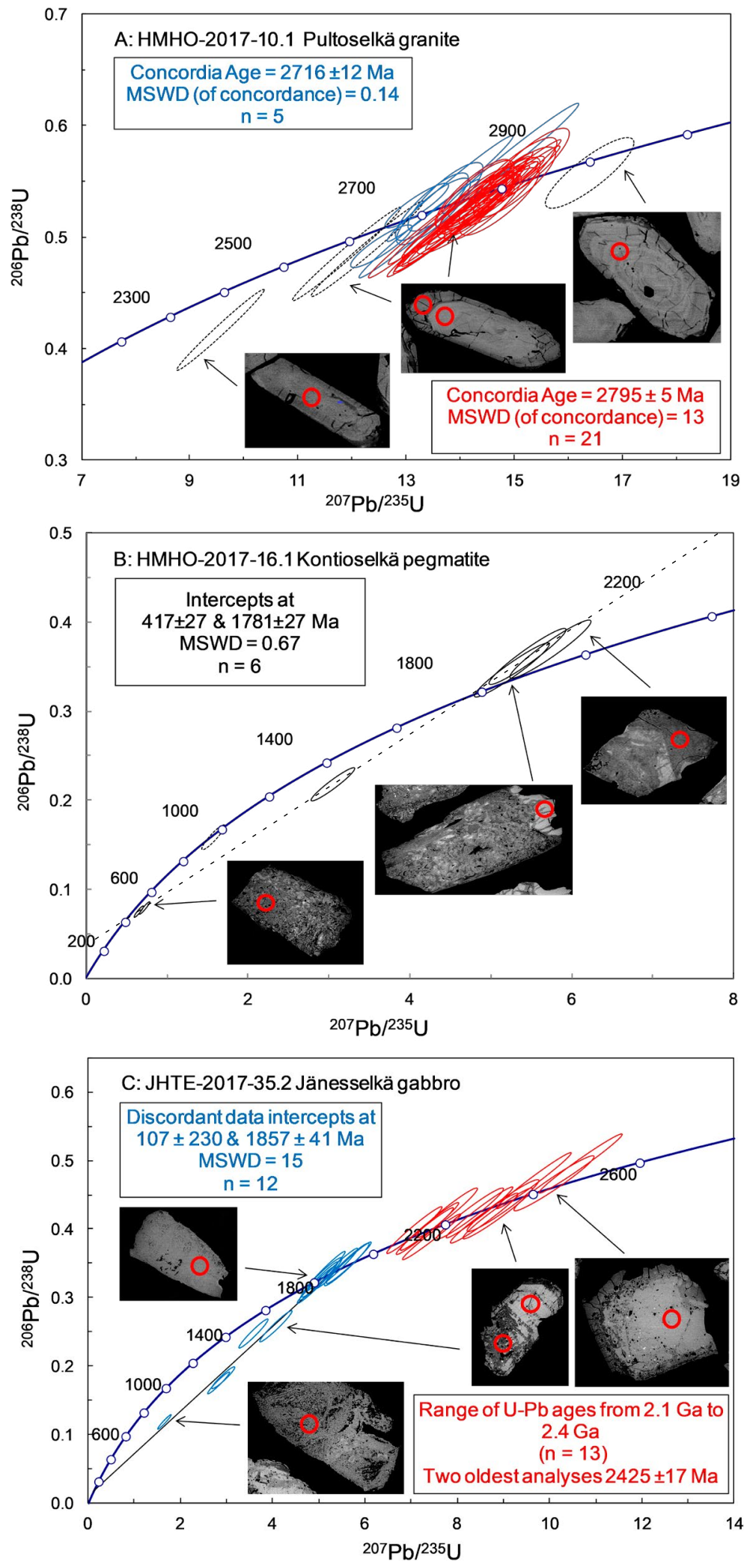

Figure 2. U-Pb zircon isotope data on the studied samples shown in concordia diagrams (Athrough C). LA-ICP-MS analyses of individual spots are shown as $2 \sigma$ error ellipsoids. Also shown are BSE images of representative zircon grains with red circles indicating positions of laser ablation spots. In A, two distinct age groups of sample $\mathrm{HMHO}$ 2017-10.1 (Pultoselkä granite), are marked with red and blue ellipsoids. In C, older concordant data of sample JHTE-2017-35.2 (Jänesselkä gabbro) are shown as red ellipsoids, younger data as blue ellipsoids. 
a discordia with the younger concordant population (see Fig. 2C) with intercepts at $1857 \pm 41 \mathrm{Ma}$ and $107 \pm 230 \mathrm{Ma}$. These results define three populations that differ from each other also in terms of their $\mathrm{Th} / \mathrm{U}$ ratios. The higher $\mathrm{Th} / \mathrm{U}$ ratios (mean value at 2.2) correlate with the older concordant 2.4 to $2.1 \mathrm{Ga}$ age group, whilst younger concordant grains have a mean $\mathrm{Th} / \mathrm{U}$ of 0.16 . The $\mathrm{Th} / \mathrm{U}$ ratio of the discordant data varies from 0.5 to 2.11 . $\mathrm{Pb}-\mathrm{Pb}$ age data are consistent with the obtained $\mathrm{U}-\mathrm{Pb}$ data and the oldest concordant domain yield a $\mathrm{Pb}-\mathrm{Pb}$ age of $2422 \pm 15 \mathrm{Ma}$. We conclude that the best estimation for the emplacement age of the gabbro is ca. 2.4 Ga.

\section{Discussion}

\subsection{Age of Pultoselkä and implication for Archean crustal evolution}

The U-Pb zircon age of $2795 \pm 5 \mathrm{Ma}$ of the Pultoselkä granite (Fig. 2A) is comparable to the emplacement ages of the nearby Marjavaara syenite (U-Pb age $2795 \pm 20$ Ma; Fig. 1) and the Suurkovanselkä alkali syenite (U-Pb age $2805 \pm 80 \mathrm{Ma}$; Fig. 1) (Juopperi \& Vaasjoki, 2001) indicating that the Pultoselkä granite was emplaced penecontemporaneously with the Marjavaara and possibly also with the Suurkovanselkä intrusions. These data and the crosscutting relationships suggest a minimum age of $\geq 2.79$ for the Tulppio suite (see Juopperi $\&$ Vaasjoki, 2001). The age of the Pultoselkä granite and the adjacent syenites at ca. 2.79 Ga has also been recognized in a variety of plutonic and volcanic rocks especially in the eastern parts of the Karelia Province (Käpyaho et al., 2007; Mikkola et al., 2011; Huhma et al., 2012; Fig. 3). The age is coeval with a period of intense sequential formation of Archean crust at 2.83-2.78 Ga characterized by voluminous tonalitic magmatism (Käpyaho et al., 2006; Mikkola et al., 2011). The tonalites are often found adjacent to coeval mafic-ultramafic volcanic rocks (Mikkola et al., 2011; Huhma et al., 2012), as in the Pultoselkä area. Tonalites and other igneous rocks with similar Archean ages have been reported widely from e.g. Kuhmo (Käpyaho et al., 2007; Huhma et al., 2012), Suomussalmi (Mikkola et al., 2011) and Russian Karelia (Bogdanova \& Bibikova, 1993). As the Archean crust formation is extensive in the Karelia Province, and the age of the Pultoselkä granite is contemporary (Fig. 3), it seems likely that the Pultoselkä records the same widespread magmatic event.

In contrast, two felsic intrusions registering the same age as the younger zircon domains (U-Pb age at 2716 \pm 12 Ma; Fig. 2A) are found ca. $50 \mathrm{~km}$ south of Pultoselkä in the Naruska granitoid complex (Juopperi \& Vaasjoki, 2011; Fig. 1). As there is no prior evidence of ca. $2.71 \mathrm{Ga}$ felsic magmatism proximate to Pultoselkä, the isotopic composition of the younger concordant domains is considered to have been subsequently modified in the consequence of a radiogenic lead-loss event or metamorphism postdating the emplacement of the Pultoselkä granite. The ca. $2.71 \mathrm{Ga}$ age is relatively widespread in the Karelia Province, however, and the lack of evidence for contemporary magmatism within the northern parts of the WKS could be merely due to poor exposure (Fig. 3).

The ca. 2.71 Ga age registered at Pultoselkä is similar to the emplacement age of late Archean 2.74-2.70 Ga sanukitoids in the Kuhmo region (Käpyaho et al., 2006), 2.74-2.70 Ga sanukitoids in the Suomussalmi region (Heilimo et al., 2011; Mikkola et al., 2011), and late-tectonic granitoid massifs in Russian Karelia with an U-Pb age of $2713 \pm 3 \mathrm{Ma}$ (Samsonov et al., 2004). Coeval ages are also registered by ca. 2.73-2.71 Ga granites and granodiorites in the Central Karelia Subprovince, where, because of high degree of discordance, the ages are considered to have been altered by a later thermal event (Vaasjoki et al., 1993). Similarly, metamorphic zircon growth at $2.73-2.70 \mathrm{Ga}$ is recognized in Archean migmatites in the KuhmoSuomussalmi area (Käpyaho et al., 2007). Hereby, it is considered that the younger zircon ages at Pultoselkä record a crustal heating event linked to those plutonic episodes, as also emphasized by 


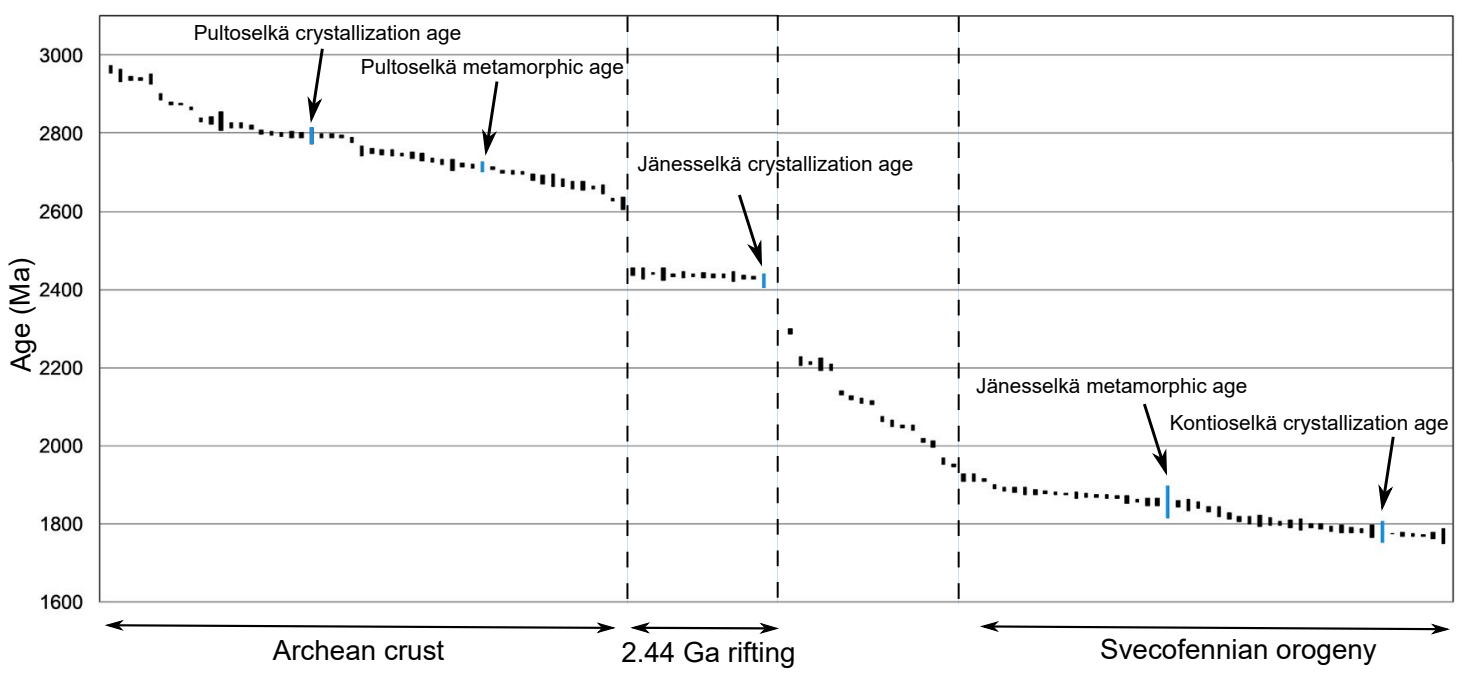

Figure 3. U-Pb age distribution of representative igneous samples analysed from the Karelia Province. Data compiled from Geological Survey of Finland Isotope data of Finnish Bedrock -database (http://gtkdata.gtk.fi/ $\mathrm{MDaE} /$ index.html). The new data from this study are shown with blue markers.

Bibikova et al. (2001), Käpyaho et al. (2006), and Käpyaho et al. (2007). The darker, homogenous recrystallized domains and the significantly lower abundance compared to the dominant zircon fraction support this idea. Accordingly, we conclude the $2795 \pm 5 \mathrm{Ma}$ age is the igneous age of the Pultoselkä granite and that the Pultoselkä granite represents the same voluminous Archean crust formation event at 2.83-2.78 Ga which has been identified elsewhere in the Archean parts of the Karelia Province.

\subsection{Age of the Kontioselkä pegmatite and relation to magmatism and metamorphism in adjacent areas}

The U-Pb data from the Kontioselkä granite pegmatite zircon fraction are rather discordant and somewhat scattered (Fig. 2B), reflecting significant post-magmatic modification of the U-Pb system. Analysis of the three oldest zircon domains yielded a $\mathrm{Pb}-\mathrm{Pb}$ age of $1811 \pm 20 \mathrm{Ma}$ suggesting a maximum age of ca. $1.81 \mathrm{Ga}$ for the pegmatite, or the upper intercept age of $1781 \pm 27$ Ma suggesting a ca. $1.75 \mathrm{Ga}$ age for the pegmatite.

All the previously acquired ca. $1.8-1.75 \mathrm{Ga}$ ages from the northern parts of the WKS have been interpreted metamorphic and related to the Svecofennian orogeny (Juopperi \& Vaasjoki, 2001, Huhma et al., 2018). Anatectic 1.8-1.75 Ga pegmatitic dykes, however, have been reported from the adjacent Belomorian Belt in Russia (Tugarinov \& Bibikova, 1980). Yet, the late Paleoproterozoic granitic intrusions of $\mathrm{ca} .1 .76 \mathrm{Ga}$ age seem to be rather ubiquitous in central Lapland (Lauerma, 1982; Corfu \& Evins, 2002; Ahtonen et al., 2007; Lauri et al., 2012) and the 1.79-1.77 Ga age period has been regarded as the main stage of the generation of granitoids in the central Lapland (Ranta et al., 2015). Associated granites and ca. $1.78 \mathrm{Ga}$ pegmatite have also been reported from the Archean eastern parts of the Karelia Province (Vaasjoki et al., 2001). In addition, this age has been recognized in hydrothermally altered carbonatesulfide veins, where it is considered to represent resetting of the U-Pb system (Mänttäri, 1995). The same resetting event is also recorded by the ca. $1.77 \mathrm{Ga}$ lamprophyres that have been interpreted to record the latest major stage of metamorphism in central Lapland (Rastas et al., 2001). 
The age of the Kontioselkä pegmatite is consistent with previously published igneous $\mathrm{U}-\mathrm{Pb}$ ages from the Karelia Province (Fig. 3). This supports the idea that the major period of deformation and metamorphism, associated with granitic magmatism around $1.76 \mathrm{Ga}$ (e.g. Corfu \& Evins, 2002; Ahtonen et al., 2007; Lauri et al., 2012), had a wider effect on the Archean of the eastern Lapland than currently anticipated. Even though there is no prior evidence of 1.76 Ga granitic magmatism within the northeastern parts of the WKS, we conclude that the $1781 \pm 27 \mathrm{Ma}$ age represents the best estimate of the igneous age of the Kontioselkä pegmatite, and at the same time defines a minimum age for the mafic volcanic rocks in Kontioselkä. The pegmatite is proposed to represent an anatectic melt related to the $1.76 \mathrm{Ga}$ thermal episode. Previously, the $1.8 \mathrm{Ga}$ age has been proposed to represent the last significant thermal event in the central parts of the Fennoscandian Shield, ending the orogenic evolution and marking the beginning of a rapid cooling period (Vaasjoki et al., 2001). We conclude that the crystallization of the Kontioselkä pegmatite represents the same evolutionary phase. The cooling was not simultaneous but instead took place more slowly in some parts of the Karelia Province as previously proposed by Vaasjoki et al. (2001). Although not conclusive, the lower intercept age at $417 \pm 27 \mathrm{Ma}$ may have geological significance, potentially related to the Caledonian orogeny.

\subsection{Age of the Jänesselkä ultramafic body and relation to $2.44 \mathrm{Ga}$ layered mafic-ultramafic intrusions}

The scattered zircon U-Pb data obtained from the gabbroic unit of the Jänesselkä ultramafic body (Fig. 2C) register multiple geological events. We suggest that the age of $2425 \pm 17 \mathrm{Ma}$ obtained from the most pristine zircon domains represent the best estimate of the igneous age of the Jänesselkä gabbro. This age is similar to the Paleoproterozoic maficultramafic layered intrusions, around $2440 \mathrm{Ma}$ in age, prominent in northern Fennoscandia (Alapieti et al., 1990) (Fig. 3). These intrusions pinpoint the first major period of Paleoproterozoic mafic magmatism in the Karelia Province (Huhma et al., 2018) and are considered to indicate a break-up of an Archean continent (Mertanen et al., 1999; Buchan et al., 2000). Numerous determinations of largely coeval ages have been conducted on these intrusions in the central (Mutanen \& Huhma, 2001; Huhma et al., 2018), western (Perttunen \& Vaasjoki, 2001), and eastern Finnish Lapland (Alapieti et al., 1982; Manninen \& Huhma, 2001; Huhma et al., 2018), as well as in Russian Karelia (e.g. Balashov et al., 1993; Amelin et al., 1995).

The Sm-Nd isotope compositions of the ca $2.44 \mathrm{Ga}$ Peuratunturi, Koulumaoiva, and Värriö intrusions within the Tuntsa suite (Fig. 1) are also consistent with the general characteristics of magmatic rocks intruded at 2.5-2.4 Ga elsewhere (Huhma et al., 2018). The effect of Svecofennian orogeny is recorded in the Sm-Nd data of Värriö intrusion (Huhma et al., 2018). In Jänesselkä, the zircon grains show obvious signs of alteration and the younger concordant grains $(2.4-1.8 \mathrm{Ga})$ could reflect gradual $\mathrm{Pb}$ loss possibly related to metamorphic effect of Svecofennian orogeny, observed in Värriö, rather than inheritance. Several altered zircon domains that yield a concordia age of ca. $1.8 \mathrm{Ga}$ are considered to have had an initially high $\mathrm{U}$ content resulting in more thorough metamictization and resetting of the U-Pb system during the peak Svecofennian metamorphism at ca. $1.8 \mathrm{Ga}$.

\section{Conclusions}

The U-Pb ages of the three studied lithologic units from eastern Lapland improve the understanding of the geochronology of the north Western Karelia Subprovince. Altogether, the three new $\mathrm{U}-\mathrm{Pb}$ dating results concur rather well with pre-existing results from the adjacent areas. The age of the Pultoselkä granite $(2795 \pm 5 \mathrm{Ma})$ shows that Archean felsic magmatism, part of 
a widespread Archean crust formation ca. 2.83$2.78 \mathrm{Ga}$, is indisputable in the northern part of the WKS. The younger ca $2.71 \mathrm{Ga}$ age clearly implies that the Archean crust was reworked during a 2.74-2.70 Ga crustal heating event associated with e.g. sanukitoid formation. The $2425 \pm 17 \mathrm{Ma}$ age for the Jänesselkä mafic-ultramafic body emphasizes the fact that 2.44 Ga mafic-ultramafic layered intrusions prevail in the Archean complexes within the north WKS, even though their amount and distribution is poorly known. Based on the established $\mathrm{U}-\mathrm{Pb}$ data it seems evident that Jänesselkä was later metamorphosed as a part of the 1.9-1.8 Ga Svecofennian orogeny. Emplacement of the Kontioselkä granite pegmatite indicates that the tectonothermal impact of the orogeny on the area may be more extensive than currently anticipated. The age of the Kontioselkä pegmatite $(1781 \pm 27 \mathrm{Ma})$ may represent the beginning of a cooling period subsequent to the Svecofennian orogeny.

\section{References}

Ahtonen, N., Hölttä, P. \& Huhma, H., 2007. Intracratonic Palaeoproterozoic granitoids in northern Finland: prolonged and episodic crustal melting events revealed by $\mathrm{Nd}$ isotopes and $\mathrm{U}-\mathrm{Pb}$ ages on zircon. Bulletin of the Geological Society of Finland 79, 143-174.

https://doi.org/10.17741/bgsf/79.2.002

Alapieti, T. T., 1982. The Koillismaa Layered igneous complex, Finland - its structure, mineralogy and geochemistry, eith emphasis on the distribution of chromium. Geological Survey of Finland, Bulletin 319, 116 p.

Alapieti, T. T., Filén, B. A., Lahtinen, J. J., Lavrov, M. M., Smolkin, V. F. \& Voitsekhovsky, S. N., 1990. Early Proterozoic layered intrusions in the northeastern part of the Fennoscandian Shield. Mineralogy and Petrology 42, 1-22. https://doi.org/10.1007/BF01162681

Amelin, Y. V, Heaman, L. M. \& Semenov, V. S., 1995. U-Pb geochronology of layered mafic intrusions in the eastern Baltic Shield: implications for the timing and duration of Paleoproterozoic continental rifting. Precambrian Research 75, 31-46. https://doi.org/10.1016/0301-9268(95)00015-W

Balashov, Y. A., Bayanova, T. B. \& Mitrofanov, F. P., 1993. Isotope data on the age and genesis of layered basicultrabasic intrusions in the Kola Peninsula and northern Karelia, northeastern Baltic Shield. Precambrian Research 64, 197-205. https://doi.org/10.1016/0301-9268(93)90076-E

\section{Acknowledgements}

This paper is based on the lead author's M.Sc. thesis (Tepsell, 2018; O.T. Rämö and A. Heinonen, supervisors), which was compiled in the framework of a collaborative project (Modeling of $\mathrm{Ni}-(\mathrm{Cu}-\mathrm{PGE})$ bearing mineral systems; the origin, exploration potential, and metallogeny of ultramafic volcanic suites of eastern Lapland) of Geological Survey of Finland and the University of Helsinki carried out in 2017-2019 to study the Ni-Cu-PGE potential of the Archean ultramafic rocks in eastern Lapland. In particular, we would like to thank Tuomo Törmänen and the technical field staff of the GTK Rovaniemi office for generous help in the course of the project. The staff of the GTK Isotope Geology unit provided valuable help with the U-Pb analyses. Leena Järvinen is acknowledged for help in preparing zircon mounts for laser work. Laura Lauri and an anonymous reviewer provided comments that improved the content and layout of the paper.

Bedrock of Finland - DigiKP. Digital mad database [electronic resource]. Espoo: Geological Survey of Finland (referred 10 April 2019), version 2.2., available at: https:/gtkdata.gtk.fi/Kalliopera/index.html

Belousova, E. A., Griffin, W. L. \& Reilly, S. Y. O., 2006. Zircon Crystal Morphology, Trace Element Signatures and Hf Isotope Composition as a Tool for Petrogenetic Modelling: Examples From Eastern Australian Granitoids. Journal of Petrology 47, 329-353. https://doi.org/10.1093/petrology/egi077

Bibikova, E., Skiöld, T., Bogdanova, S., Gorbatschev, R. \& Slabunov, A., 2001. Titanite-rutile thermochronometry across the boundary between the Archaean Craton in Karelia and the Belomorian Mobile Belt , eastern Baltic Shield. Precambrian Research 105, 315-330. https://doi.org/10.1016/S0301-9268(00)00117-0

Bingen, B., Andersson, J., Söderlund, U. \& Möller, C., 2008. The Mesoproterozoinc in the Nordic coutries. Episodes 31, 29-34. https://doi.org/10.18814/epiiugs/2008/v31i1/005

Bogdanova, S. V. \& Bibikova, E. V., 1993. The "Saamian" of the Belomorian Mobile Belt: new geochronological constraints. Precambrian Research 64, 131-152. https://doi.org/10.1016/0301-9268(93)90072-A

Buchan, K. L., Mertanen, S., Park, R. G., Pesonen, L. J., Abrahamsen, N. \& Bylund, G., 2000. Comparing the drift of Laurentia and Baltica in the Proterozoic: the 
importance of key palaeomagnetic poles. Tectonophysics 319, 167-198.

https://doi.org/10.1016/S0040-1951(00)00032-9

Corfu, F. \& Evins, P. M., 2002. Late Palaeoproterozoic monazite and titanite $\mathrm{U}-\mathrm{Pb}$ ages in the Archaean Suomujärvi Complex , N-Finland. Precambrian Research $116,171-181$. https://doi.org/10.1080/00206814.2019.1611488

Gaál, G. \& Gorbatschev, R., 1987. An Outline of the Precambrian Evolution of the Baltic Shield. Precambrian Research 35, 15-52. https://doi.org/10.1016/0301-9268(87)90044-1

Haapala, P., 2019. Petrological and geochemical comparison of the ultramafic rocks of Tulppio, Jänesselkä, and Värriöjoki eastern Finnish Lapland. M.Sc. Thesis, University of Helsinki, Finland, 110 p.

Haapala, P., Höytiä, H. \& Tepsell, J., 2019. Itä-Lapin mineraalipotentiaalikartoituksen karttaprojektin työvaiheet ja DigiKP:n päivitys 2018-2019. In: Köykkä, J. \& Luukas, J. (eds.), GTK work report 67/2019, GTK/ 331/00.03.13/2019. Geological Survey of Finland, Rovaniemi, Finland, $30 \mathrm{p}$ (in Finnish).

Heilimo, E., Halla, J. \& Huhma, H., 2011. Single-grain zircon $\mathrm{U}-\mathrm{Pb}$ age constraints of the western and eastern sanukitoid zones in the Finnish part of the Karelian Province. Lithos 121, 87-99. https://doi.org/10.1016/j.lithos.2010.10.006

Hölttä, P., Balagansky, V., Garde, A., Mertanen, S., Peltonen, P., Slabunov, A., Sorjonen-Ward, P. \& Whitehouse, M., 2008. Archean of Greenland and Fennoscandia. Episodes 31, 13-19. https://10.18814/epiiugs/2008/v31i1/003

Huhma, H., Mänttäri, I., Peltonen, P., Kontinen, A., Halkoaho, T., Hanski, E., Hokkanen,T., Hölttä, P., Juopperi, H., Konnunaho, J., Layahe, Y., Luukkonen. E., Pietikäinen.K., Pulkkinen, A., Sorjonen-Ward, P., Vaasjoki, M. \& Whitehouse, M., 2012. The Age of the Archean Greenstone Belts in Finland. In: Hölttä P. (ed.), The Archaean of the Karelia Province in Finland. Geological Survey of Finland, Special Paper, 54, 74-175.

Huhma, H., Hanski, E., Kontinen, A., Vuollo, J. \& Lahaye, Y., 2018. Sm-Nd and U-Pb isotope geochemistry of the Palaeoproterozoic mafic magmatism in eastern and northern Finland. Geological Survey of Finland, Bulletin 405, 153 p.

Jackson, S. E., Pearson, N. J., Griffin, W. L. \& Belousova, E. A., 2004. The application of laser ablation-inductively coupled plasma-mass spectrometry to in situ U-Pb zircon geochronology. Chemical Geology 211, 47-69. https://doi.org/10.1016/j.chemgeo.2004.06.017

Juopperi, H., 1994. Arkeeinen kallioperä Itä-Lapissa. 13102 Final report K/21.42/94/9. Geological Survey of Finland, Rovaniemi, Finland, 17 p (in Finnish).

Juopperi, H. \& Vaasjoki, M. 2001. U-Pb mineral age determinations from Archean rocks in eastern Lapland. In: Vaasjoki M. (ed.), Radiometric age determinations from Finnish Lapland and their bearing on the timing of
Precambrian volcano-sedimentary sequences. Geological survey of Finland, Special Paper 33, 209-228.

Käpyaho, A., Mänttäri, I. \& Huhma, H., 2006. Growth of Archaean crust in the Kuhmo district, eastern Finland: $\mathrm{U}-\mathrm{Pb}$ and $\mathrm{Sm}-\mathrm{Nd}$ isotope constraints on plutonic rocks. Precambrian Research 146, 95-119. https://doi.org/10.1016/j.precamres.2006.01.006

Käpyaho, A., Hölttä, P. \& Whitehouse, M. J., 2007. U-Pb zircon geochronology of selected Archaean migmatites in eastern Finland. Bulletin of the Geological Society of Finland 79, 95-115.

https://doi.org/10.17741/bgsf/79.1.005

Kauniskangas, E., 1987. Savukosken koillisosan arkeeisten liuskeiden petrografia ja geokemia. Project on Archean areas report 35. University of Oulu, Department of Geology, 92 p (in Finnish).

Koistinen, T., Stephens, M.B., Bogatchev, V., Nordgulen, Ø., Wennerström, M. \& Korhonen, J., 2001. Geological map of Fennoscandian Shield, scale 1:2,000,000. Geological Survey of Finland, Norway and Sweden and the NorthWest Department of Natural Resources of Russia.

Lauerma, R., 1982. On the ages of some granitoid and schist complexes in northern Finland. Bulletin of the Geological Society of Finland 54, 85-100.

https://doi.org/10.17741/bgsf/54.1-2.009

Lauri, L. S., Andersen, T., Räsänen, J. \& Juopperi, H., 2012. Temporal and $\mathrm{Hf}$ isotope geochemical evolution of southern Finnish Lapland from 2.77 Ga to 1. 76 Ga. Bulletin of the Geological Society of Finland 84, 121140. https://doi.org/10.17741/bgsf/84.2.002

Ludwig, K. R., 2003. Isoplot/Ex 3. A Geochronological Toolkit for Microsoft Excel. Berkeley Geochronologicy Center, Special Publication No. 4.

Luukas, J., Kousa, J., Nironen, M. \& Vuollo, J., 2017. Major stratigraphic units in the bedrock of Finland, and an approach to tectonostratigraphic division. In: Nironen, M. (ed.), Bedrock of Finland at the scale 1:1000000 - Major stratigraphic units, metamorphism and tectonic evolution. Geological Survey of Finland, Special Paper 60, 9-39.

Manninen, T. \& Huhma, H., 2001. A new U-Pb zircon constraints from Salla Schist belt, norhern Finland. In: Vaasjoki M. (ed.), Radiometric age determinations from Finnish Lapland and their bearing on the timing of Precambrian volcano.sedimentary sequences. Geological survey of Finland, Special Paper 33, 209-228.

Mertanen, S., Halls, H. C., Vuollo, J. I., Pesonen, L. J. \& Stepanov, V. S., 1999. Paleomagnetism of $2.44 \mathrm{Ga}$ mafic dykes in Russian Karelia , eastern Fennoscandian Shield - implications for continental reconstructions. Precambrian Research 98, 197-221. https://doi.org/10.1016/S0301-9268(99)00050-9

Mikkola, E., 1936. Bedrock map of Tuntsajoki 1:400000, Maps of Pre-Quarternary rocks D7, Map sheet 47, Geological Survey of Finland. 
Mikkola, E., 1941. Muonio-Sodankylä-Tuntsajoki. Explanation to the General Geological Map of Finland, sheets B7-C7-D7, 286 p (in Finnish with English description).

Mikkola, P., Huhma, H., Heilimo, E. \& Whitehouse, M., 2011. Lithos Archean crustal evolution of the Suomussalmi district as part of the Kianta Complex, Karelia: Constraints from geochemistry and isotopes of granitoids. Lithos, 125, 287-307.

https://doi.org/10.1016/j.lithos.2011.02.012

Mutanen, T. \& Huhma, H., 2001. U-Pb geochronology of the Koitelainen, Akanvaara and Keivitsa layered intrusions and related rocks. Special Paper of the Geological Survey of Finland 33, 229-246.

Mänttäri, I., 1995. Lead isotope characteristics of epigenetic gold mineralization in the Paleoproterozoic Laplan greenstone belt, northern Finland. Geological Survey of Finland, Bulletin 381, 90p.

Nironen, M., 2017. Guide to the Geological Map of Finland - Bedrock 1:1000000. Special Paper of Geological Survey of Finland, 60, 40-74.

Papunen, H. (ed.), Halkoaho, T., Kilpeläinen, T., Lepistö, S., Liimatainen, J., Lyons, K., Tulenheimo, T. \& Välimaa, J., 1997. Savukosken Tulppio alueen kartoitukset kesällä 1997. Technical Report, Integrated technologies for mineral exploration pilot project for nickel ore deposits, University of Turku, Department of Geology, $50 \mathrm{p}$ (in Finnish).

Peltoniemi, H., 1984. Savukosken koillisosan proterotsooiset kivet. Project on Archeanareas report 17. University of Oulu, Department of Geology, 52 p (in Finnish).

Perttunen, V. \& Vaasjoki, M., 2001. U-Pb geochronology of the Peräpohja Schist Belt, northwestern Finland. In: Vaasjoki M. (ed.), Radiometric age determinations from Finnish Lapland and their bearing on the timing of Precambrian volcano.sedimentary sequences. Geological survey of Finland, Special Paper 33, 209-228.

Piirainen, T., Virransalo, P. \& Kauniskangas, E., 1985. Savukosken osaprojektintutkimusalueen geologia. In: Piirainen, T. (ed.), Arkeeisten alueiden malmiprojektin loppuraportti. Arkeeisten alueiden malmiprojekti 25, University of Oulu, Department of Geology, 140-178 (in Finnish).

Ranta, J., Lauri, L. S., Hanski, E., Huhma, H. \& Lahaye, Y., 2015. U - Pb and $\mathrm{Sm}-\mathrm{Nd}$ isotopic constraints on the evolution of the Paleoproterozoic Peräpohja Belt, northern Finland. Precambrian Research 266, 246-259. https://doi.org/10.1016/j.precamres.2015.05.018

Rastas, P., Huhma, H., Hanski, E., Lehtonen, M. I., Härkönen†, I., Kortelainen, V., Mänttäri I. \& Paakkola, J., 2001. U-Pb isotopic studies on the Kittilä Greenstone area, Central Lapland Finland. In: Vaasjoki M. (ed.), Radiometric age determinations from Finnish Lapland and their bearing on the timing of Precambrian volcanosedimentary sequences. Geological survey of Finland, Special Paper 33, 95-141.
Samsonov, A. V., Bibikova, E. V. \& Puchtel, I. S., 2004. Magnesian Granitoids (Sanukitoids) of the Kostomuksha Area, Western Karelia: Petrology, Geochronology, and Tectonic Environment of Formation. Petrology 12, 437 468.

Slabunov, A. I., Lobach-Zhuchenko, S. B., Bibikova, E. V., Balagansky, V. V., Sorjonen-Ward, P., Volodichev, O. I., Shchipansky, A. A., Svetov, S. A., Chekulaev, V. P., Arestova, N. A. \& Stepanov, V. S., 2006. The Archean of the Baltic Shield: Geology, Geochronology, and Geodynamic settings. Geotectonics 40, Pleiades Publishing, 409-433. https://doi.org/10.1134/S001685210606001X

Stacey, J. S. \& Kramers, J. D., 1975. Approximation of terrestrial lead isotope evolution by a two-stage model. Earth and Planetary Science Letters 26, 207-221. https://doi.org/10.1016/0012-821X7590088-6

Tepsell, J., 2018. Geokronologia ja Cu-Fe-S-isotooppisovellukset Itä-Lapin ultraemäksissä komplekseissa ja niihin liittyvissä litologisissa yksiköissä. M.Sc. thesis, University of Helsinki, Finland, 126 p (in Finnish).

Tugarinov, A. I. \& Bibikova, E. V., 1980. Geochronology of Baltic Shield by zircon age determinations. Moscow, Nauka, Moscow, 130 p.

Vaasjoki, M., Sorjonen-Ward, P. \& Lavikainen, S., 1993. U-Pb age determination and sulfide $\mathrm{Pb}-\mathrm{Pb}$ characteristics from the late archean Hattu Schist Belt. Geological Survey of Finland, Special Paper 17, 103-131.

Vaasjoki, M., Kärki, A. \& Laajoki, K., 2001. Timing of Paleoproteroxoic crustal shearing in the Central Fennoscandian Shield according to U-Pb data from associated granitoids, Finland. Bulletin of the Geological Society of Finland 73, 87-101. https://doi.org/10.17741/bgsf/73.1-2.007

Van Achterbergh, E., Ryan, C., Jackson, S. \& Griffin W., 2001. Data reduction software for LA-ICP-MS, In: Sylverster P. (Ed.), Laser-Ablation ICPMS in the Earth Sciences - Principles and applications, Mineralogical Association of Canada short course series, 29, St John, Newfoundland, 239-243.

Vartiainen, H. \& Woolley, A. R., 1974. The age of the Sokli carbonatite, Finland, and some relationships of the North Atlantic alkaline igneous province. Bulletin of the Geological Society of Finland 46, 81-91. https://doi.org/10.17741/bgsf/46.1.010

Virransalo, P., 1985. Savukosken koillisosan kalioperän stratigrafia, rakenne ja metamorfoosi. In: Piirainen, T. (ed.), Arkeeisten alueiden malmiprojektin loppuraportti. Arkeeisten alueiden malmiprojekti 24, University of Oulu, Department of Geology, 76 p (in Finnish). 